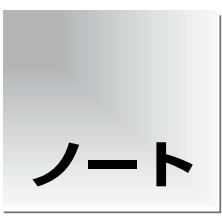

論文受付 2010 年 3 月 8 日 論文受理 2010 年 9 月14 Code No. 251

\section{デジタルファントムと臨床画像を用いた肝臓領域における 低コントラスト分解能の評価}

\author{
原田耕平 ${ }^{1)}$ ・宮下宗治 ${ }^{2)}$ ・平野雄士 ${ }^{3)}$ ・片倉俊彦 ${ }^{4}$ \\ 1 ) 札幌医科大学附属病院放射線部 \\ 2) 医療法人耳鼻咽喉科麻生病院診療支援部 \\ 3) 社団法人日本海員掖済会小樽病院技術管理部 \\ 4) BBMIL センター
}

\section{緒 言}

近年, multi detector row computed tomography(MDCT) の進化により撮影が高速化し，16列以上の装置では 肝臓領域においても 1 相あたりにおける撮影時間が 5 秒 程度となっている。これは single detector row computed tomography (SDCT)の肝ダイナミックスタディ ${ }^{1)}$ に比べ 時間分解能が大幅に向上したことを示し, 肝臓領域 の検査法は確立したといえる2).しかし一方で, 被ば く量の問題 ${ }^{3 \sim 5}$ が表面化し, 撮影線量の適正化が求め られているのが現状である。 この問題を解決すべく自動 露出機構 (auto exposure control system: AEC) 機能6 9) を搭載した装置が次々に登場し, 線量の適正化が現
実的に可能となってきている. しかし，肝細胞癌 (HCC; Hepatocellular carcinoma)を検出できる具体的 な CT 值差や最低腫瘍径は明確な基準がない. 肝茞 領域において撮影線量を最適化するには，適正な画 質をどこに設定するかが問題となる。したがって，こ の領域では低コントラスト分解能の評価が必須とな る.デジタルファントムは $512 \times 512$ ピクセルの元画像 にさまざまなピクセルサイズとコントラスト差を持つ 模擬腫瘤を配置した digital imaging and communications in medicine(DICOM)画像である。今回われわれ は，デジタルファントムを任意の座標に任意のピクセ ルサイズ，コントラスト差にて作成可能なデジタル

\title{
Evaluation of Low-contrast Resolution for Liver Image in Digital Phantom and Clinical Image
}

Kohei Harada, ${ }^{1)}$ Soji Miyashita, ${ }^{2)}$ Yushi Hirano,, ${ }^{3)}$ and Toshihiko Katakura4)

1 ) Division of Radiology, Sapporo Medical University Hospital

2) Azabu Triology Hospital

3) Nihon Kaiin Ekisaikai Otaru Hospital

4) BBMIL Center

Received March 8, 2010; Revision accepted September 14, 2010; Code No. 251

\section{Summary}

The high performance of multi detector-row computed tomography (MDCT), enables a flow dynamic study of the liver that can be carried out within 10 seconds per one phase. In addition, it has been possible to obtain a stable image quality by utilizing the auto exposure control system. However, no clear standard of minimal CT value differences and minimal tumor sizes for detecting liver tumors has ever been shown. In order to help in their standardization, we developed novel software to make an arbitrary digital phantom. The limit of space occupied lesion (SOL) detection in each image quality could be determined by a detection study using digital phantoms superimposed on liver CT images. As a result, the detection rate of simulated tumors was significantly different, in comparisons of different image qualities for the late arterial phase and in comparison between the late arterial and equilibrium phases for the same image quality. Our method could help standardize the scan conditions for performing a liver CT.

Key words: multi detector row computed tomography (MDCT), digital phantom, low contrast resolution, liver, clinical image 


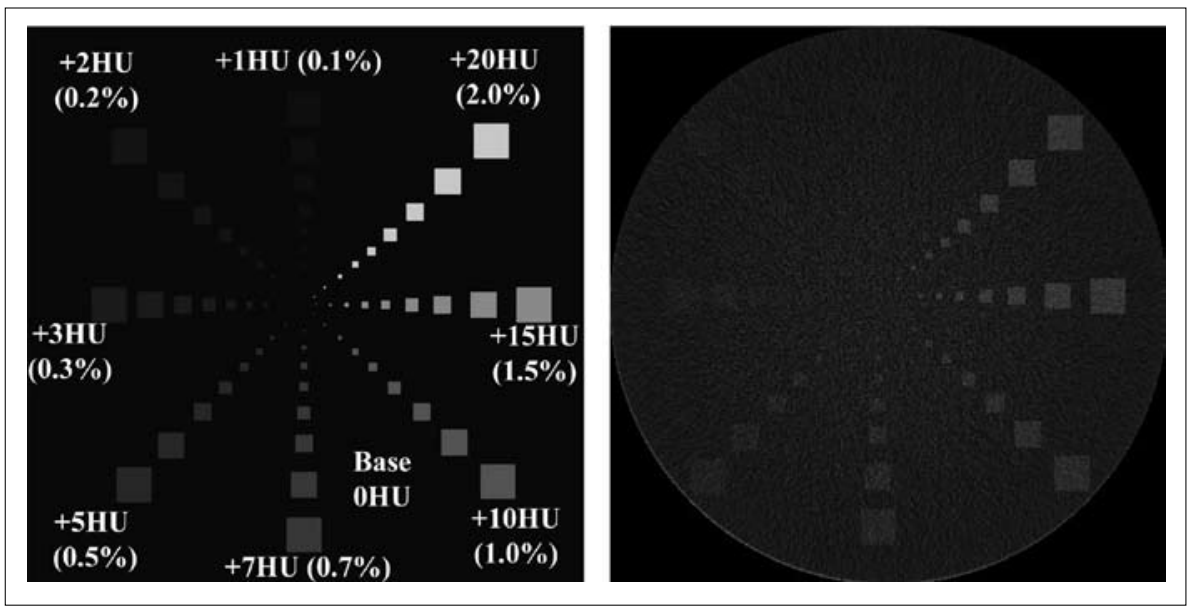

Fig. 1 (a) Digital phantom (prototype), (b) Digital phantom + water phantom (additional image).

ファントム作成ツールを開発した，本研究では作成し たデジタルファントムと臨床画像を用いて低コントラ スト分解能の評価を行い, 肝臓領域における動脈後 期相，平衡相での描出限界についての検討を行った.

\section{1. 方 法}

\section{1-1 使用装置・撮影条件}

使用装置として Aquilion M16(東芝社製)を用いた。 この装置の AEC 設定は水ファントムを撮影したとき の水の CT 值に対する standard deviation $(\mathrm{SD})[\mathrm{HU}]$ に 相当する仕組みである，撮影条件は管電圧 $120 \mathrm{kVp}$, 管電流 $\mathrm{AEC}(\mathrm{SD} 8.0$ および $\mathrm{SD} 10.0)$ ，収集スライス 厚 $1 \mathrm{~mm} * 16$, HP 15(BP 0.9375), C-FOV $320 \mathrm{~mm}$, 再構成スライス厚 $5 \mathrm{~mm}$, 再構成間隔 $5 \mathrm{~mm}$, 再構成 関数 FC 10 である. 撮影方法はボーラストラッキング法 を用い，横隔膜レベルの腹部大動脈に関心領域を設定 した．動脈後期相は CT 值が $250 \mathrm{HU}$ に達してから 10 秒後に撮影を開始，平衡相は 180 秒にて撮影した.

\section{1-2 対 象}

対象は2005 年 9 月から 2006 年 9 月までに肝 3 phase studyを行った 40 例(AEC[SD 8.0]で撮影した 20 例およびAEC [SD 10.0]で撮影した 20 例，男性 25 名, 女性 15 名, 平均年齢 $64.4 \pm 11.8$ 歳)である.

\section{1-3 デジタルファントムと作成ツール}

デジタルファントム (prototype)を Fig. 1a に示す.

$512 \times 512$ マトリクスのなかに異なる大きさ，異なる CT 值を単純にプロットしたものである. $0.1 \%$ か 2\%までの CT 值差のものが各ピクセルの大きさで配列 してある. 水ファントムにデジタルファントムを加算 した画像を Fig. 1b に示す。このように他の DICOM

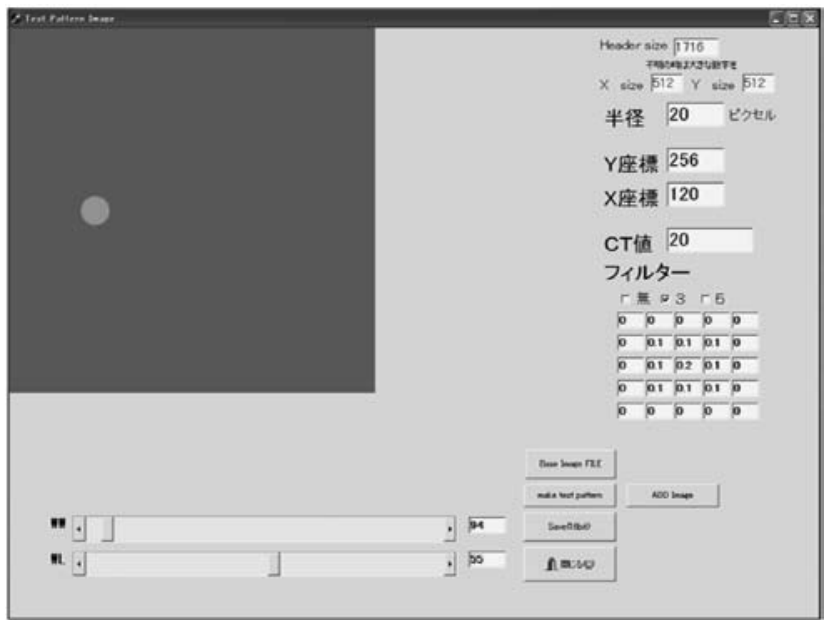

Fig. 2 Digital phantom creation tool.

data に加算することで視覚的評価を行う。デジタル ファントムの特徴は，ピクセルサイズによって大きさ が変動することである。したがって，評価を行うには 加算画像の再構成 field of view(FOV)を一定にする 必要がある。

しかし，このデジタルファントムを臨床画像に加算 すると，形状が四角であること，ファントムが並んで いるために先入観が入ることなどの問題点が指摘で きる.われわれはこの問題点を解決し, デジタルファ ントムを臨床画像に加算して評価を行うために, ファン トムの大きさ，コントラスト差，座標を任意に設定可能 なデジタルファントム作成ツールを開発した(Fig. 2). ファントム形状は円形とし，フィルタをかけることで ファントム周囲の profile が急峻になることを抑制可 能とした。その結果, より $\mathrm{SOL}$ (占拠性病変 : space occupying lesion)に模擬することができる(Fig. 3). 任 意の座標をプロットし, $\mathrm{CT}$ 值, フィルタの值を入力 


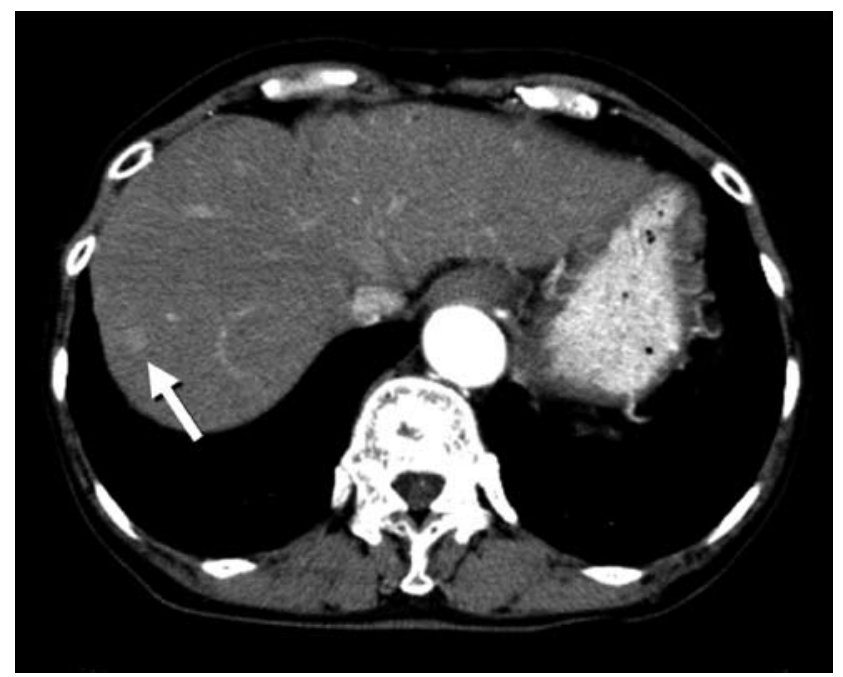

Fig. 3 Digital phantom + clinical image (additional image).

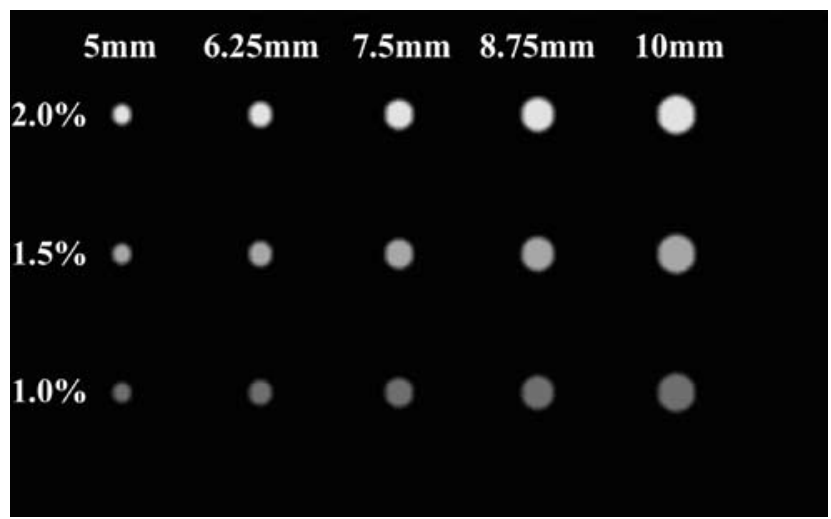

Fig. 4 Digital phantom.

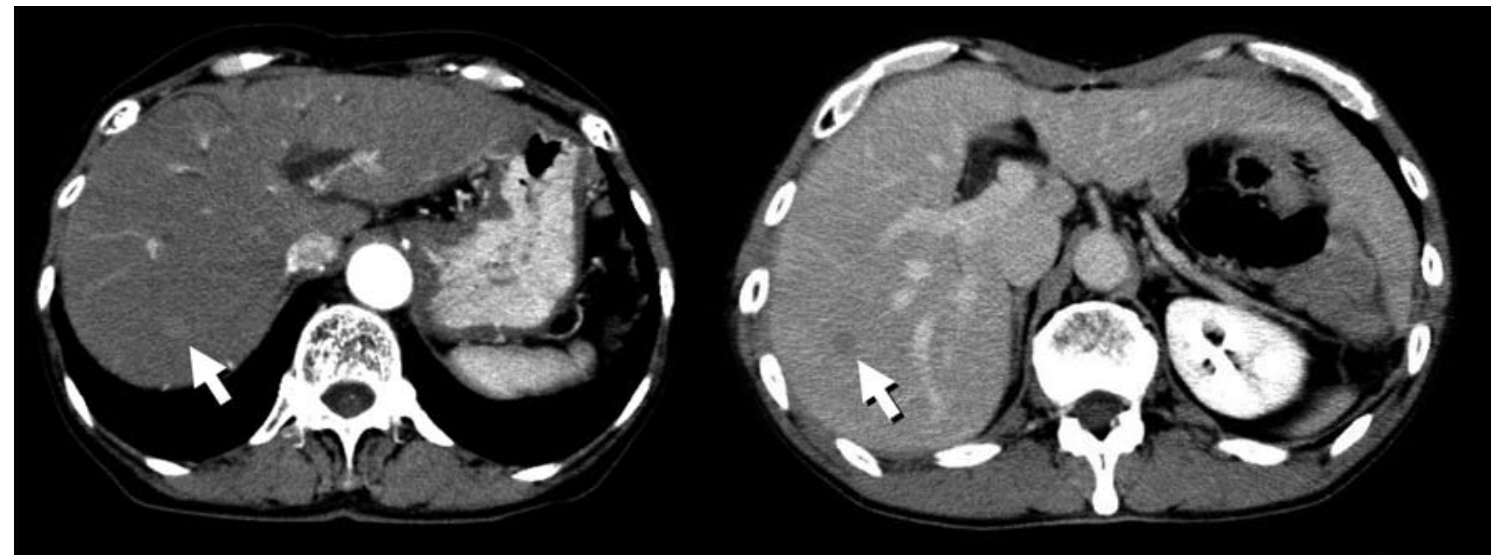

Fig. 5 (a) Digital phantom + clinical image (Early phase), (b) Digital phantom + clinical image (Delayed phase).

することで，自在にデジタルファントムを作成するこ とが可能である。作成した画像はデジタルファントム 画像, 臨床データとの加算画像を個々にDICOM 保 存可能とした.

\section{1-4 デジタルファントム加算画像の作成}

加算するデジタルファントムは大きさが 5 種類, $\mathrm{CT}$ 值差が 3 種類の計 15 種類とした. 臨床画像の再 構成 FOV $320 \mathrm{~mm}$ に設定したことによりデジタル ファントムの大きさはそれぞれ $5 \mathrm{~mm}(8$ pixel $), 6.25 \mathrm{~mm}$ (10 pixel), $7.5 \mathrm{~mm}(12$ pixel $), 8.75 \mathrm{~mm}(14$ pixel $), 10 \mathrm{~mm}$ (16 pixel)となる. CT 值差は $2.0 \%, 1.5 \%, 1.0 \%$ の 3 種類とした(Fig. 4)。この 15 種類のデジタルファント 厶を各 20 個ずつ計 300 個作成し, 臨床画像の肝実質 に血管と重ならないように無作為に加算した。できる だけ先入観を排除するため 1 スライス中に加算するデ ジタルファントムの個数を限定せず，0 個から最大 3
個加算するスライスも存在した

動脈後期相の画像ではデジタルファントムを単純 に加算することで，周囲肝実質よりも high density areaとして描出させ, 平衡相の画像ではマイナスの CT 值を加算することにより，周囲肝実質よりも low density area として描出させた(Fig. 5a, b).

作成した画像は $4 \times 5$ にて半切フィルムに出力し, すべて同一のシャウカステンにより評価を行った.

\section{1-5 評価方法}

1 名の内科医(経験 24 年), 3 名の診療放射線技師 (経験 17 年, 15 年, 8 年)の 4 名にて視覚評価を行った. 1 コマずつシェーマを描き，検出した部位にマーキン グすることでデジタルファントム加算部位との照合を 行った。評価方法は各デジタルファントム検出数の平 均值と標準偏差を求め, 同一濃度差, 同一画質内で の 5 種類の大きさにおける検出限界，異なる画質間 


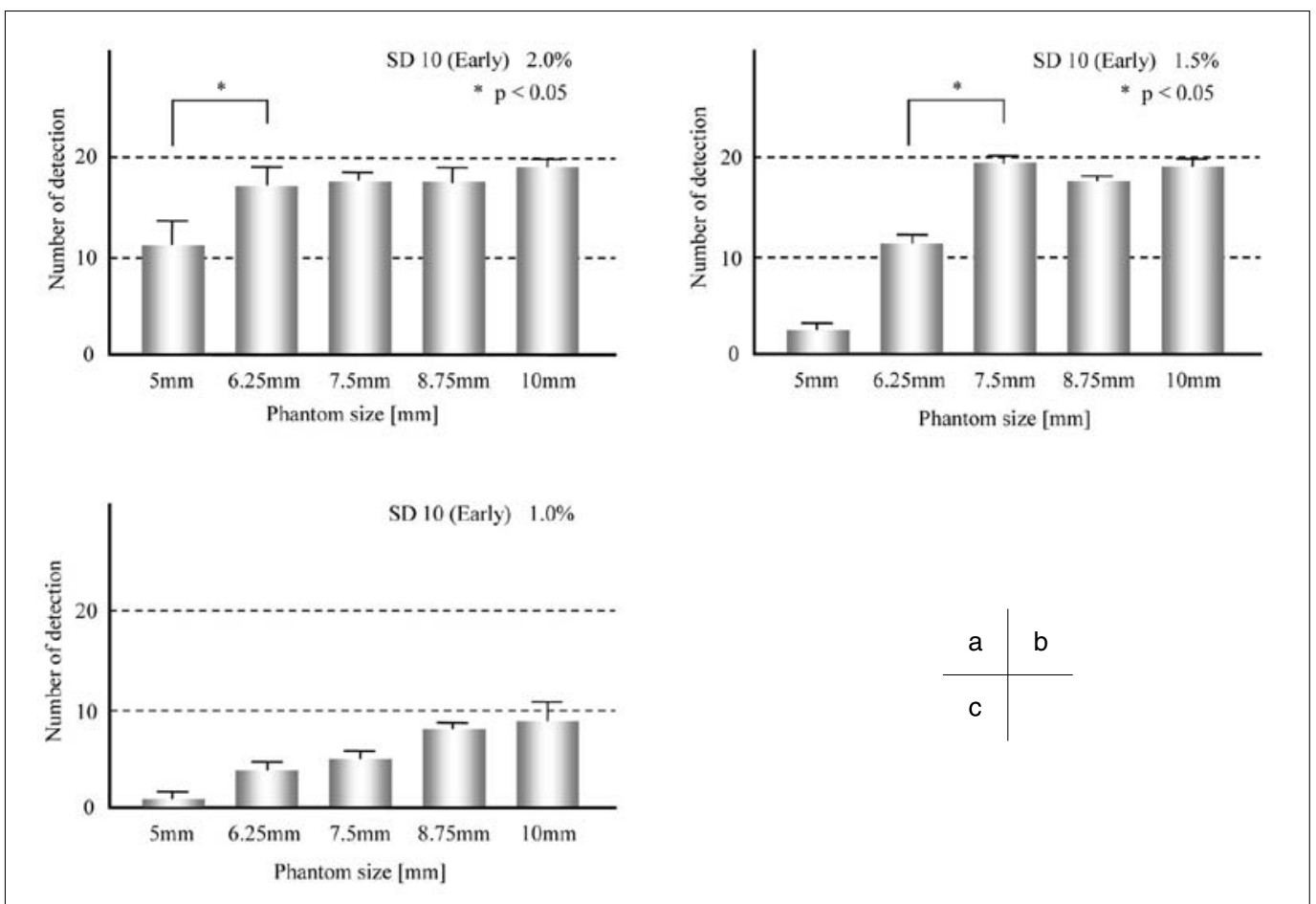

Fig. 6 Numbers of detection in image of each phantom by size (SD 10, Early phase).
(a) Contrast $2.0 \%$
(b) Contrast $1.5 \%$
(c) Contrast $1.0 \%$

での同一濃度差，同一径における比較，および同一 濃度差，同一画質間，同一径においての動脈後期相と 平衡相の検出能を比較した，検定は Tukey-Kramer test による多重比較分析，および student $\mathrm{t}$ を用い，有意 水準 $\mathrm{p}<0.05$ にて有意差ありとした.

\section{1-6 倫 理}

研究に先立ち, 画像評価の段階で一切の個人情報を 排除すること, 本研究以外には使用しないこと, 患者 本人に不利益が生じることはないことを十分説明し， 画像評価の際に患者の匿名化を行い，評価者に患者 を特定できないようにした。

\section{2. 結 果}

\section{2-1 動脈後期相 (SD 10，SD 8) における結果}

SD 10(2.0\%)では 5 6.25 mm 間において有意差を 認め, SD 10(1.5\%)では 6.25〜 7.5 mm 間において有意 差を認めた. SD 10(1.0\%)では全体的に検出数が低く, 信憑性にそしい結果となった(Fig.6)。これに対し， SD 8 群では $2.0 \% ， 1.5 \% ， 1.0 \%$ いすれに执いても5〜 $6.25 \mathrm{~mm}$ 間に有意差を認めた(Fig.7)。同一 CT 值差 に扮けるSD 10 群と SD 8 群の比較では，2.0\%では 有意差を認めず， $1.5 \%$ では $5 \mathrm{~mm}, 6.25 \mathrm{~mm}$ におい てそれぞれ有意差を認めた。1\%ではほとんどの大き
さに打いて有意差を認め, 大きさ $5 \mathrm{~mm}$ のみ検出数 が少なく, 有意差なしとなった(Fig.8).

\section{2-2 平衡相 (SD 10)における結果}

平衡相における各大きさによる比較では， $2.0 \%$, $1.5 \%, 1.0 \%$ いずれにおいても5〜6.25 mm 間に有意 差を認めた(Fig.9). 同一画質(SD 10)における動脈後期 相と平衡相の比較を Fig. 10 に示す. $2.0 \%, 1.5 \%$, 1.0\%ほぼ有意差を認め, $1.5 \%, 7.5 \mathrm{~mm}$ および $1.5 \%$, $10 \mathrm{~mm}$ のみ有意差を認めなかった。

\section{3. 考 察}

同一画質内に扔ける検討では, SD 10 群, SD 8 群 いずれにおいても濃度差が低く，大きさが小さくなる につれ検出数は減少する傾向にあった。さらに SD 8 群では大きさによる検出限界はいずれも 5 6.25 mm 間にあると推測されるのに対し，SD 10 群では濃度差の 違いにより大きさの検出限界も異なる結果となった. 今回の検討では, SD 10 群と SD 8 群を比較した場合, 濃度差 $1.5 \%$ ，大きさ $6.25 \mathrm{~mm}$ に扔いて有意差を認め, ここに検出能の境界があることが示唆された。また， 濃度差 $1 \%$ の検出数が極端に低く, 両者に有意差は 認めたものの，検出率が 6 割を超えるものはなく，信 憑性に乏しいと考えられる。平衡相に扔ける検討で 


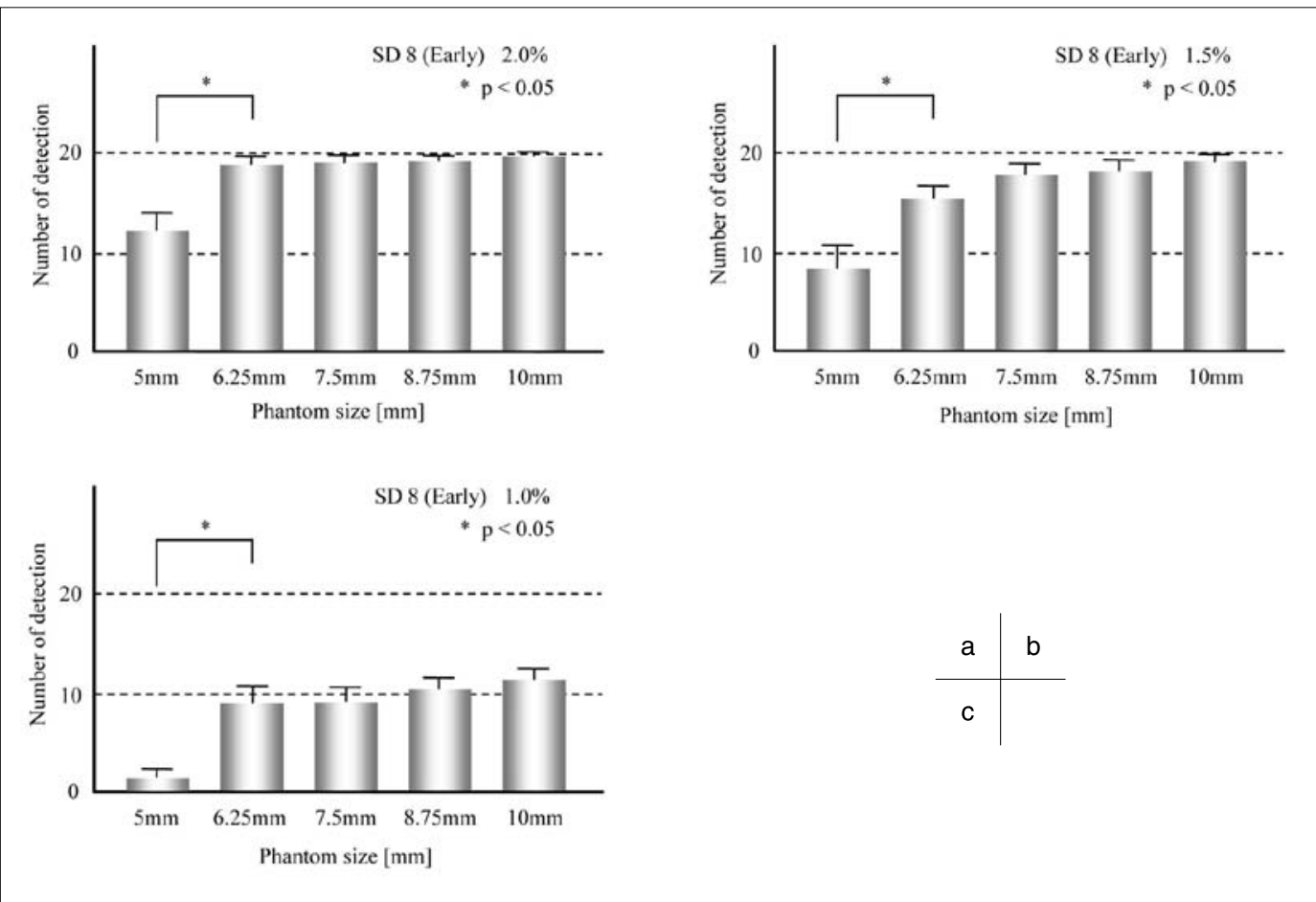

Fig. 7 Numbers of detection in image of each phantom by size (SD 8, Early phase).

(a) Contrast $2.0 \%$

(b) Contrast 1.5\%

(c) Contrast 1.0\%
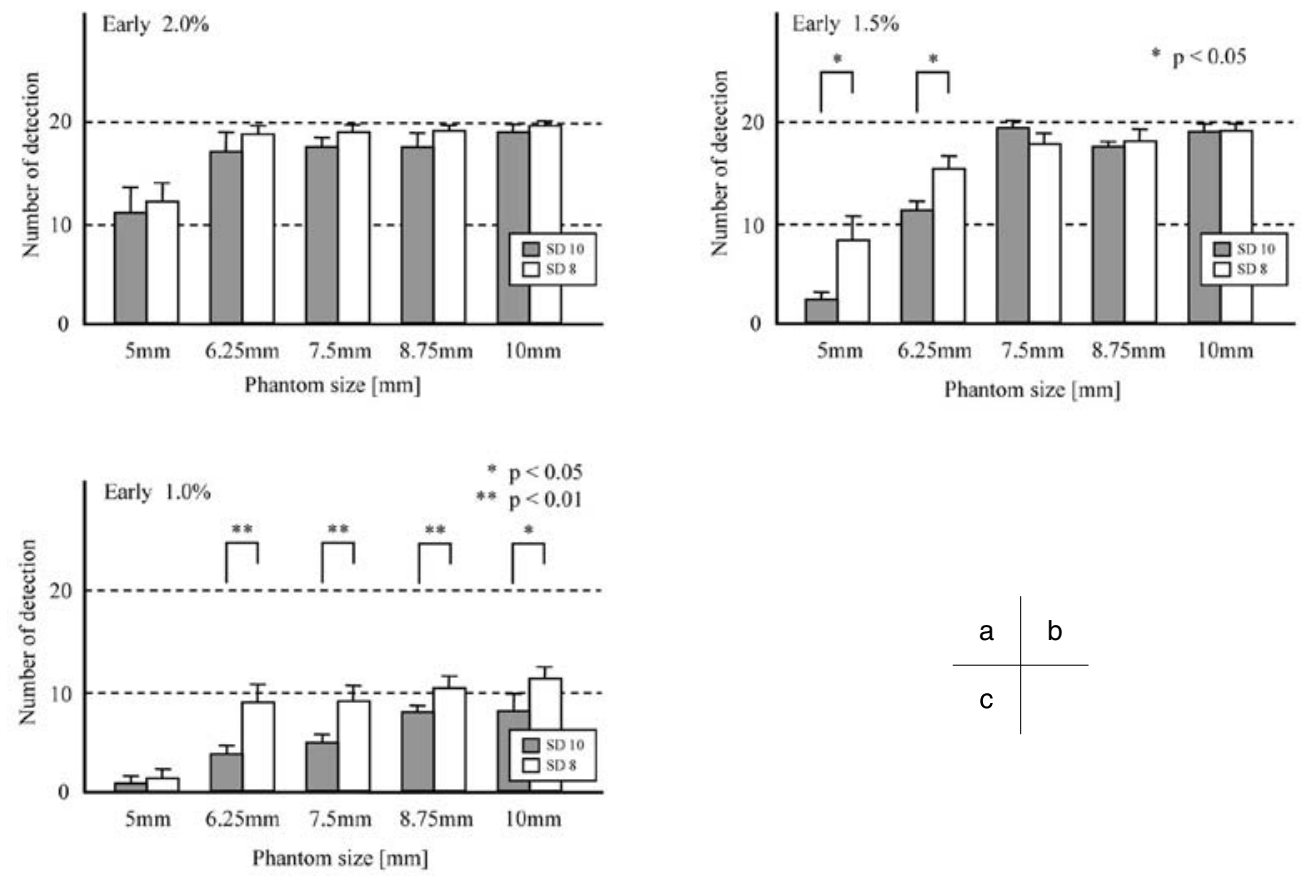

Fig. 8 Comparison of numbers of detection in image of the same density difference (SD 10, Early vs. SD 8, Early).

(a) Contrast $2.0 \%$

(b) Contrast $1.5 \%$

(c) Contrast $1.0 \%$ 


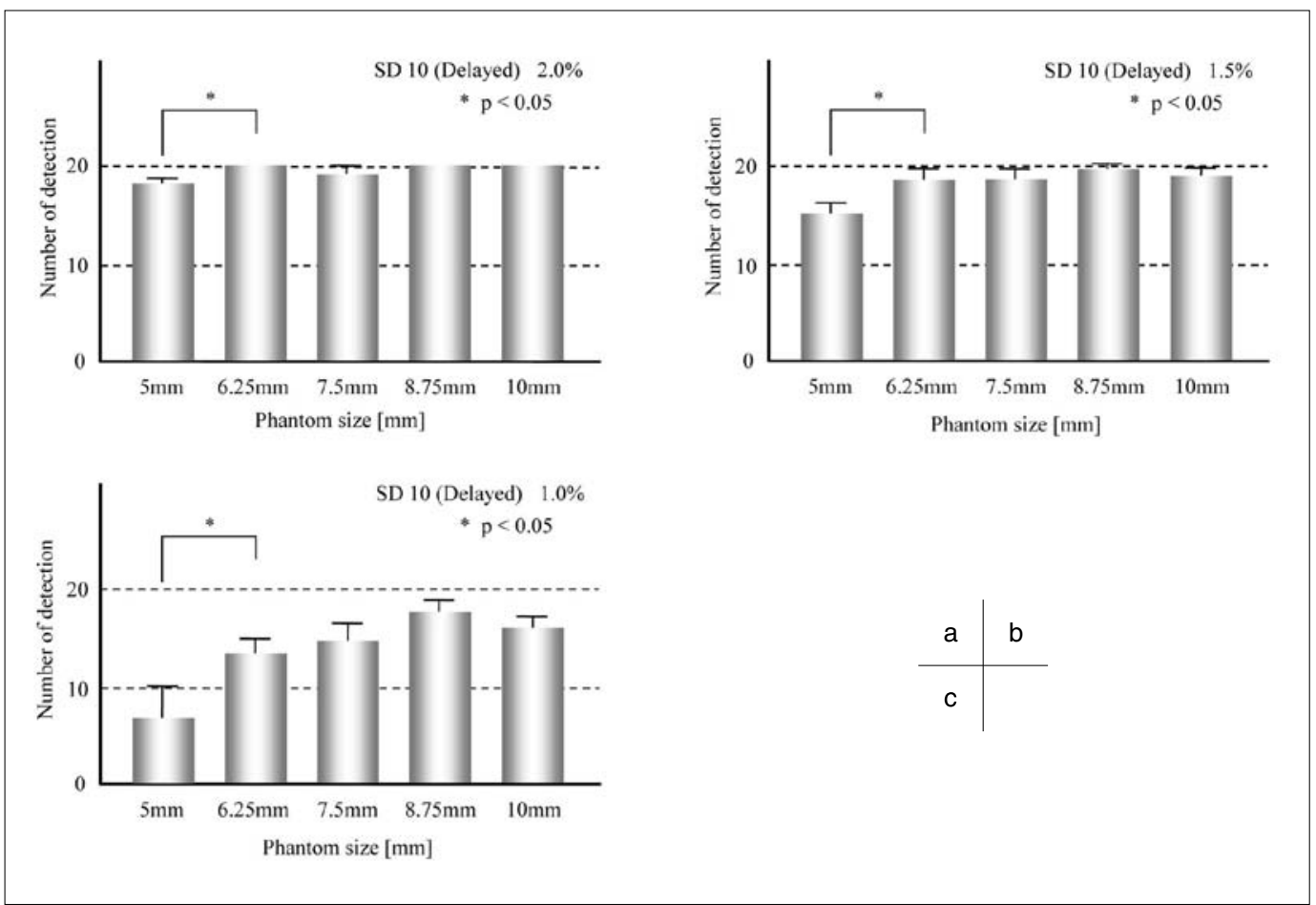

Fig. 9 Numbers of detection in image of each density phantom by size (SD 10, Delayed phase).
(a) Contrast $2.0 \%$
(b) Contrast 1.5\%
(c) Contrast 1.0\%

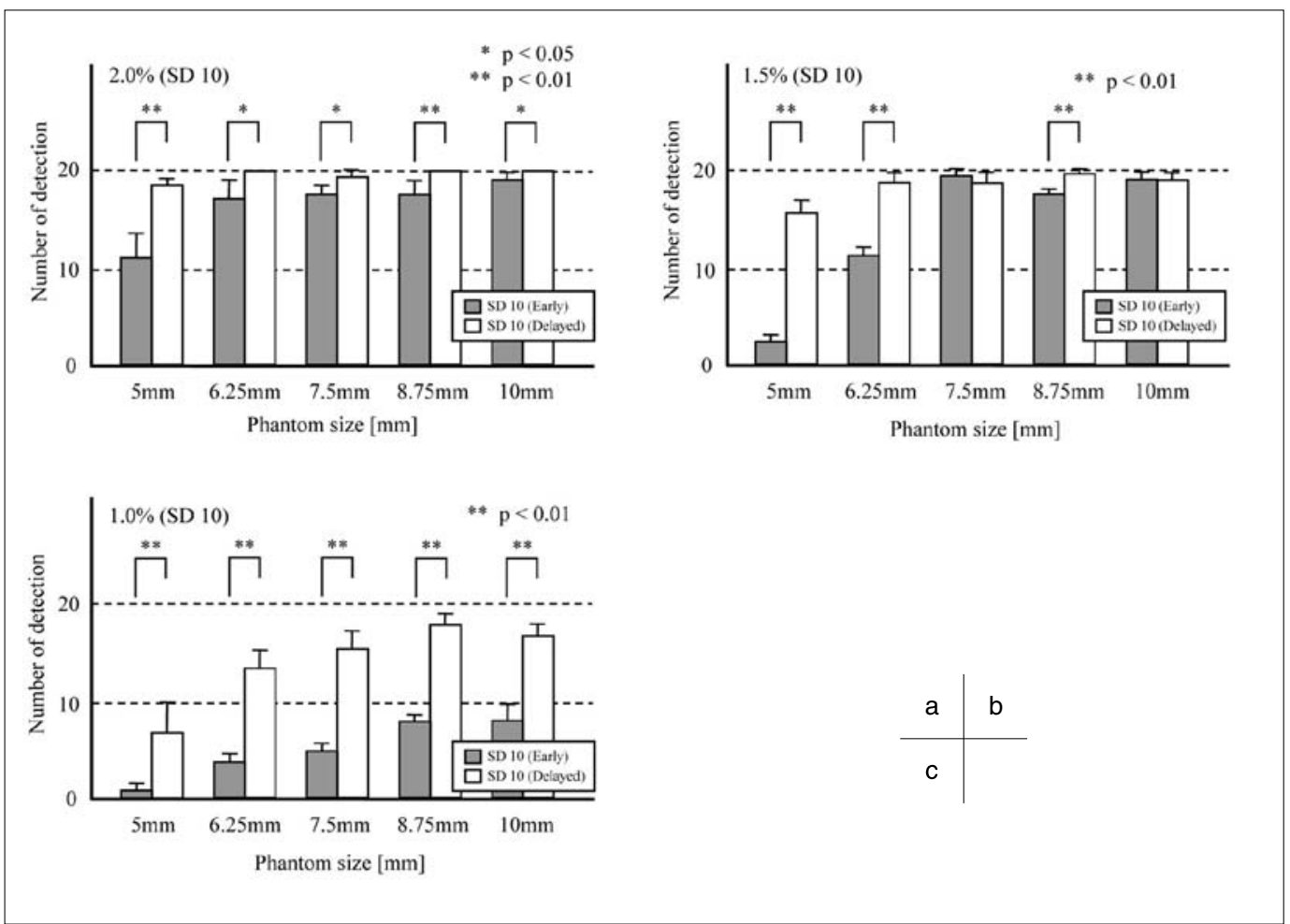

Fig. 10 Comparison of numbers of detection in image of the same density difference (SD 10, Early vs. SD 10, Delayed).
(a) Contrast $2.0 \%$
(b) Contrast 1.5\%
(c) Contrast $1.0 \%$ 
は動脈後期相に比べ全体的に検出数が高い結果と なった．同一画質同士にもかかわらず両者の差は歴 然であり，有意差を認めなかった $1.5 \%, 7.5 \mathrm{~mm}$ およ び $1.5 \%, 10 \mathrm{~mm}$ においても評価者の人数を増やすこ とで同様に差が出ることが推察される。肝蔵領域で は肝細胞癌の検索において, 動脈後期相では正常肝 実質よりも high density の領域を探索し, 平衡相では 正常肝実質よりも low density の領域を模索する。動 脈後期相では, 動脈, 門脈は正常肝実質よりも高吸 収に, 肝静脈は低吸収領域として表現され，さまざ まな濃度が混在した画像のなかで病変を示唆する high density area を検索するのは困難を極める。これ に対し平衡相では正常肝実質はやや高吸収に，さら に脈管は正常肝実質よりも高吸収領域として描出さ れるため，そのなかで low density areaを検索するの は前者に比べ容易であると推察される。動脈後期相 ではファントム径が小さくなるほど脈管との区別がつ かなくなり，実際には視認できるにもかかわらず検出

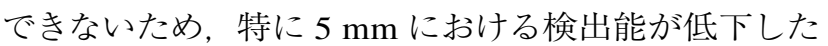
と考える. また, 本法はフィルムによる観察方法を用 いているが，モニタ診断では画像をページングにて 観察するため, フィルムに比べ連続性の評価に優れ ていることから， ワンランク高い評価を得ることが可 能であると予測する。

今回の検討ではいくつかの問題点も明確となつた. 一つめは作成した模擬腫瘤に臨床画像と同一の周波 数特性が加味されていない点である。単純に CT 值を 加算しているため, わずかではあるが過大評価されて いる可能性がある. 二つめはファントムにかけたフィル 夕処理が, 特に少ないピクセル数で構成された模擬
腫瘤に影響を与えた可能性がある，最後に今回作成し たファントムは 2D であり，体軸方向の連続性，および パーシャルボリウム効果を考慮していない点である. これらの問題点を改善することが今後の課題である.

しかし, 本研究では位相により肝蔵における血管 や実質の濃度分布が変化したことによって検出率が 影響を受けた。 これは低コントラスト分解能ファントム 等を用いた物理評価とは大きく異なる特徵をもっている と考える. しかしながら, 残念なことに肝の臨床画像 において具体的な検出サイズや濃度差についてのエ ビデンスが示されていないため，現段階では施設ご とに基準を設けるなどの措置をとるに留まると考えられ ることから, 早急にガイドライン等の策定が望まれる.

今回提案したデジタルファントムは, retrospective に 評価を行う方法であることから，画像評価を行うために 「実験」する必要もなく，日常自分たちが撮影している 臨床画像そのものを使って評価することができる．本法 は前述したいくつかの問題点を改善することで, 臨床画 像を評価するためのツールとして，また，読影トレーニ ングなどの教育用としても利用可能であると考える.

\section{4. 結 語}

CAD (computer assisted diagnosis; コンピュータ支 援診断)も日々進化を遂げているものの，未だ画像診 断は最終的に医師の「眼」によってなされているのが 現状である。したがって，最も臨床画像に即した条 件下で画像評価を行うことが，直接臨床現場に反映 されると考える。デジタルファントムを用いた評価方 法が今後, 低コントラスト分解能評価の一助となるこ とに期待する。

\section{参考文献}

1）清水雅史, 新武慶興, 三崎敏正, 他. 肝腫瘍に対する三 相性 CT 造影剂量, 注入プログラム, 検出能について. 日本医放会誌 1996; 56(9): 621-624.

2) Yanaga Y, Awai K, Nakaura T. Optimal contrast dose for depiction of hypervascular hepatocellular carcinoma at dynamic CT using 64-MDCT. AJR 2008; 190(4): 1003-1009.

3）西澤かな枝, 松本雅紀, 岩井一男, 他. CT 検査件数及 びCT 検査による集団実効線量の推定. 日本医放会誌 2004; 64(3): 151-158.

4) 小林正尚, 片岡由美, 井田義宏, 他. X線 CT 装置にお ける CTDI100, air を用いた線量推定法の検討. 日放技学 誌 2004; 60(11): 1526-1532.

5) Valentin J. International Commission on Radiation Protection. Managing patient dose in multi-detector computed tomography (MDCT). ICRP Publication 102. Ann ICRP 2007; 37(1): 1-79.

6) Namasivayam S, Kalra MK, Pottala KM, et al. Optimization of Z-axis automatic exposure control for multidetector row $\mathrm{CT}$ evaluation of neck and comparison with fixed tube current technique for image quality and radiation dose. AJNR Am J Neuroradiol 2006; 27(10): 2221-2225.

7) Tsukagoshi S, Ota T, Okumura M, et al. Simulator-assisted setting of scan protocols for X-ray CT: development and clinical usefulness of the scan plan simulator. Nippon Hoshasen Gijutsu Gakkai Zasshi. 2006; 62(1): 95-104.

8) Muramatsu Y, Ikeda S, Osawa K, et al. Performance evaluation for CT-AEC (CT automatic exposure control) systems. Nippon Hoshasen Gijutsu Gakkai Zasshi 2007; 63(5): 534-545.

9) Papadakis AE, Perisinakis K, Damilakis J. Automatic exposure control in pediatric and adult multidetector CT examinations: a phantom study on dose reduction and image quality. Med Phys 2008; 35(10): 4567-4576. 


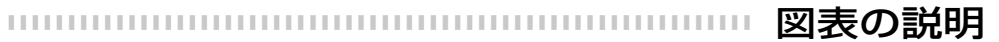

Fig. 1 （a）デジタルファントム(プロトタイプ), （b）デジタルファントム + 水ファントム (加算画像)

Fig. 2 デジタルファントム作成ツール

Fig. 3 デジタルファントム + 臨床画像 (加算画像)

Fig. 4 今回作成したデジタルファントム (15 種類)

Fig. 5 (a)デジタルファントム＋臨床画像 (動脈後期相), (b)デジタルファントム + 臨床画像 (平衡相)

Fig. 6 各大きさにおける検出数 (SD 10, 動脈後期相)
(a) CT 值差 $2.0 \%$
(b) CT 值差 $1.5 \%$
(c) CT 值差 $1.0 \%$

Fig. 7 各大きさにおける検出数 (SD 8, 動脈後期相)
(a)CT 值差 $2.0 \%$
(b) CT 值差 $1.5 \%$
(c) CT 值差 $1.0 \%$

Fig. 8 同一 CT 值差同士に扔ける検出数の比較 (SD 10, 動脈後期相 vs SD 8, 動脈後期相)

(a) CT 值差 $2.0 \%$

(b) CT 值差 $1.5 \%$

(c) CT 值差 $1.0 \%$

Fig. 9 各大きさにおける検出数 (SD 10, 平衡相)
(a)CT 值差 $2.0 \%$
(b) CT 值差 $1.5 \%$
(c) CT 值差 $1.0 \%$

Fig. 10 同一 CT 值差同士に扔ける検出数の比較 (SD 10, 動脈後期相 vs SD 10, 平衡相)
(a) CT 值差 $2.0 \%$
(b) CT 值差 $1.5 \%$
(c) CT 值差 $1.0 \%$ 